\title{
Pengolahan Serum Hemolisis Menggunakan Reagen Anti-Rh Pada Pemeriksaan Glukosa Darah Metode GOD-PAP
}

\author{
Indah Atika ${ }^{1}$, Ira Rahmawati ${ }^{2}$, Neni Anggraeni ${ }^{3}$ \\ ${ }^{1,3}$ Sekolah Tinggi Analis Bakti Asih Bandung, Padasuka Atas No.233, Bandung, Indonesia \\ ${ }^{2}$ Poltekkes Kemenkes Malang, Malang, Indonesia
}

\section{Article Info \\ Article history: \\ Received Mar $07^{\text {th }}, 2020$ \\ Revised Jun $07^{\text {th }}, 2020$ \\ Accepted Jul 08 ${ }^{\text {th }}, 2020$}

Keyword:

Glukosa Darah, Serum Hemolisis, Anti - Rh

GOD - PAP

\begin{abstract}
Determination of glucose serum level using GOD-PAP technique can be hampered by the presence of hemoglobin within the serum sample which is caused by hemolysis. Anti-Rh reagent which is added into the serum sample can bind to the hemoglobin and therefore, can be separated from the serum sample. This study aimed to assess the effect of adding anti-Rh reagent into the hemolysis serum sample to form sediments of the hemoglobin so it can be separated from the serum. This study also assessed whether the serum sample can be used for glucose serum test after added with anti-Rh reagent. An experimental design was used evaluating glucose concentrations in serum sample with hemolysis. We then compared the glucose concentrations in hemolysis serum with glucose level in serum sample that was given anti-Rh and glucose serum level in normal serum sample. Data analysis was conducted using Friedman test. Glucose level in hemolysis serum is significantly higher compared to glucose level in normal serum with $P$ value $0,0008<\alpha(0,05)$. Meanwhile, Glucose serum test in serum sample containing anti-Rh reagent reveals no significant glucose level differences compared to the normal serum with $P$ value $0,51>\alpha(0,05)$. Similarly, the glucose level measured in hemolysis serum that had been added with anti-Rh reagent is significantly different with glucose level in the hemolysis one, with $P$ value $<\alpha(0.05)$. Therefore, anti-Rh reagent can be used to handle hemolysis serum.
\end{abstract}

Copyright $@$ Jurnal Analis Medika Biosains (JAMBS) All rights reserved.

\begin{abstract}
ABSTRAK
Pemeriksaan glukosa serum dengan metode GOD - PAP dapat diganggu dengan adanya hemoglobin di dalam serum akibat pecahnya eritrosit dan mengakibatkan serum menjadi hemolisis. Penambahan reagen anti $-\mathrm{Rh}$ kedalam serum dapat mengikat hemoglobin sehingga serum hemolisis dapat dipisahkan antara bagian serum dan bagian hemoglobinnya. Penelitian ini bertujuan untuk mengetahui pengaruh reagen anti - Rh sebagai pengendap hemoglobin pada serum hemolisis dan untuk mengetahui serum dapat digunakan kembali untuk pemeriksaan glukosa darah setelah penambahan reagen anti - Rh pada serum hemolisis. Metode penelitian ini bersifat eksperimen dengan melihat penurunan kadar glukosa darah setelah penambahan reagen anti - Rh pada serum hemolisis yang dibandingkan dengan kadar glukosa serum hemolisis yang selanjutnya dibandingkan dengan kadar glukosa serum normal. Data kemudian dianalisis dengan uji Friedman. Hasil menunjukkan serum hemolisis berbeda signifikan dengan P 0,008 yang lebih kecil dari alpha $(0,05)$ yang dibandingkan dengan serum normal. Penggunaan reagen anti - Rh pada serum hemolisis menunjukkan hasil yang tidak berbeda signifikan dengan P 0,51 yang lebih besar dari alpha $(0,05)$ dibandingkan dengan serum normal. Serum hemolisis dengan penambahan reagen anti - Rh menunjukkan hasil yang berbeda signifikan dengan P 0,008 yang lebih kecil dari alpha $(0,05)$ dibandingkan dengan serum hemolisis. Reagen anti-rh dapat digunakan dalam pengolahan serum hemolisis.
\end{abstract}




\section{Pendahuluan}

Pelayanan laboratorium kesehatan adalah pelayanan yang dapat menunjang diagnosis penyakit atau monitoring kesembuhan dari pasien. Di laboratorium, kesalahan dalam pelayanan dapat dikategorikan menjadi tiga, yaitu : kesalahan preanalitik dengan presentase kesalahan $60-70 \%$, kesalahan analitik dengan presentase kesalahan 10 - 15\%, dan kesalahan pasca analitik dengan presentase kesalahan 15 - 18\% (Kitchen et al.,2009).

Sampel yang buruk akan memberikan hasil pemeriksaan laboratorium yang tidak valid. Ada beberapa alasan yang dapat menyebakan sampel tidak layak untuk diperiksa. Salah satunya adalah serum hemolisis (Pherson \& Phincus.,2011). Pemeriksaan glukosa darah adalah pemeriksaan yang penting dalam laboratorium klinik terutama bagi pasien diabetes melitus (Bell.,2001). Penentuan kadar glukosa darah menjadi tolak ukur dalam diagnosis diabetes melitus (Bott., 2014). Metode pemeriksaan glukosa darah meliputi metode induksi enzimatik dan lainnya. Metode yang paling sering digunakan adalah metode enzimatik, yaitu metode Glukosa Oksidase (GOD) dan metode heksokinase (Hendromartono, 1998).

Telah diketahui bahwa metabolisme glukosa dalam serum pada tabung berisi darah akan mengalami penurunan seiring waktu berjalan. Saat spesimen tersebut belum diuji, proses glikolisis dapat terjadi oleh komponen - komponen selular di dalamnya dan akan menyerap gukosa sebanyak 5 - 7\% glukosa yang terdapat dalam sampel tiap jam. Penurunan tersebut kemungkinan terbesar disebabkan adanya proses glikolisis pada eritrosit (Mikesh \& Bruns, 2008; World Health Organization, 2013).

Hemoglobin adalah salah satu substansi sel darah merah yang berfungsi untuk mengangkut oksigen ke seluruh tubuh. Ketika gula darah tidak terkontrol (yang berarti gula darah tinggi) maka gula darah akan berikatan dengan hemoglobin (terglikasi). Glukosa menempel pada hemoglobin, semakin banyak atau tinggi kadar glukosa dalam darah maka hemoglobin juga akan semakin tinggi konsentrasinya mencapai 2-3\% (Widjaja, 2010). Serum lisis dapat menyebabkan pecahnya membran eritrosit sehingga hemoglobin bebas kedalam medium sekelilingnya, yaitu plasma atau serum. Kadar hemoglobin yang terdapat dalam serum yang dapat mengganggu pemeriksaan glukosa darah adalah 0,4 g/dl. (Mikesh \& Bruns, 2008; World Health Organization, 2013)

Sistem rhesus terdiri atas dua jenis yaitu rhesus positif $(\mathrm{Rh}+)$ dan rhesus negatif $(\mathrm{Rh}-)$ berdasarkan ada tidaknya antigen rhesus pada dinding sel darah merah seseorang. $\mathrm{Rh}+$ dalam darahnya memiliki antigen rhesus yang ditunjukkan dengan reaksi positif atau dijumpai adanya gumpalan sel darah merah pada waktu dilakukan tes dengan antibodi Rh (Aslinar.,2016). Pada dasarnya hemoglobin tidak boleh ada di dalam serum atau plasma karena dapat menyebabkan hasil pemeriksaan yang salah, yaitu dapat menyebabkan kenaikan atau penurunan palsu pada pemeriksaan. Salah satunya adalah pada pemeriksaan glukosa dapat menyebabkan kenaikan palsu, yang disebabkan oleh keluarnya glukosa yang terdapat pada eritrosit yang pecah (Guniar, 2012).

Hemoglobin merupakan salah satu ganguan kromogen pada metode kolorimetrik sehingga hemoglobin dikaitkan dengan absorbansi optik yang kuat pada panjang gelombang 400 - $600 \mathrm{~nm}$. Gangguan kromogen inilah yang menyebabkan peningkatan intensitas warna dimana akan terjadi peningkatan absorbansi yang dibaca oleh fotometer (Ramadhanti, 2013).

Pada uji pendahuluan yang telah dilakukan dengan menggunakan kadar hemoglobin di dalam serum 0,2 g/dl. Dengan kadar pooled serum glukosa 88,82 mg/dl, kemudian serum dibuat hemolisis sehingga kadar 
glukosanya menjadi $101,79 \mathrm{mg} / \mathrm{dl}$. Serum yang telah dibuat hemolisis ditambahkan reagen anti - Rh sehingga kadar glukosanya menjadi 77,89 mg/dl. Berdasarkan latar belakang tersebut, peneliti tertarik melakukan penelitian tentang "Pengolahan Serum Hemolisis Menggunakan Reagen Anti - Rh Pada Pemeriksaan Glukosa Darah Metode GOD - PAP”.

\section{Metode Penelitian}

Metode yang digunakan pada penelitian ini adalah eksperimen dengan static group comparison. Untuk menentukan jumlah pengulangan digunakan rumus Gomes didapatkan hasil hitung replikasi adalah $\mathrm{t} \geq 3$, sehingga penelitian dilakukan dengan pengulangan 9 kali. Sample penelitian adalah serum, serum hemolysis dan serum hemolysis yang diberi anti $\mathrm{Rh}$.

Untuk mempersiapkan sample penelitian dilakukan tindakan sebagai berikut: whole blood yang ditambahkan antikoagulan EDTA disentrifugasi dengan kecepatan 3000 rpm selama 5 menit, plasma yang terbentuk dibuang. Kemudian Sel darah yang diperoleh dicuci dengan $\mathrm{NaCl}$ 0,9\% dengan perbandingan volume 1:1 (satu bagian darah dengan satu bagian $\mathrm{NaCl}$ ) sebanyak 3 kali sampai didapatwarna supernatan yang jernih. Sel darah yang diperoleh pada akhir pencucian dipipet sebanyak 0,4 ml ke dalam tabung lain. Selanjutnya sel darah dipisah untuk dibuat hemolisat. Sel darah yang telah dicuci, ditambahkan aquadest sebanyak 0,1 ml lalu dikocok. Tabung disentrifugasi dengan kecepatan 3000 rpm selama 15 menit. Jika belum menjadi hemolisat (sel darah merah yang hemolisis), darah dikocok dan disentrifugasi kembali dengan kecepatan 3000 rpm selama 15 menit. Agar didapatkan darah hemolisat 100\%, darah dimasukkan kedalam freezer selama 1 hari, darah yang sudah beku kemudian disentrifugasi kembali Hemolisat yang dihasilkan kemudian diukur kadar Hb-nya . Hemolisat yang didapat dijadikan variasi 0,4 g/dl. Untuk mendapatkan hemolisat dengan hemoglobin yang lebih rendah maka hemolisat dengan kadar tinggi diencerkan dengan pool serum dengan volume tertentu (Guniar, 2012).

Setelah Didapatkan pool serum dan hemolisat kemudian dihitung pengenceran hemolisat yang diperlukan untuk menghasilkan kadar hemoglobin sebesar 0,4 mg/dl Ditambahkan hemolisat sebanyak $20 \mu \mathrm{l}$ ke dalam serum pada tabung dengan volume $980 \mu$ l. Dihomogenkan, lalu diperiksa kadar hemoglobin menggunakan metode cyanmethemoglobin (Guniar, 2012).

Serum hemolisis sebanyak $1 \mathrm{ml}$ ditambahkan anti-Rh sebanyak $400 \mu 1$ kemudian didiamkan selama 10 menit, kemudian disentrifugasi 1000 rpm selama 1 menit untuk kemudian dipisahkan serum dengan darah dan diukur kadar glukosa darah dengan metode GOD-PAP. Penelitian di Laboratorium Terpadu Politeknik Kesehatan Bandung. Yang dilakuakan pada bulan September 2019.

\section{Hasil Penelitian dan Pembahasan}

Dalam eksperimen ini, peneliti kadar glukosa darah pada serum hemolisis dengan konsentrasi hemoglobin 0,42 g/dl yang ditambahkan reagen anti-Rh sebanyak $400 \mu$ l. Penelitian ini menggunakan metode GOD - PAP dengan alat fotometer. Penelitian ini menggunakan hemolisat sebagai simulasi serum hemolisis dengan kadar 19,20 g/dl. Dan menggunakan sampel serum hemolisis yang ditambahkan anti - Rh dengan konsentrasi hemoglobin $0,04 \mathrm{~g} / \mathrm{dl}$. 
Jurnal Analis Medika Biosains (JAMBS)

Vol.7, No.2, September 2020, pp. 93 - 100

ISSN: 2656-2456 (Online)

ISSN: 2356-4075 (Print)

Tabel 1. Hasil Pemeriksaan Glukosa Serum Normal

\begin{tabular}{|c|c|}
\hline Sampel & $\begin{array}{l}\text { Kadar Glukosa Darah } \\
\text { Sewaktu (mg/dl) }\end{array}$ \\
\hline 1 & 98,23 \\
\hline 2 & 100,79 \\
\hline 3 & 98,56 \\
\hline 4 & 99,3 \\
\hline 5 & 97,85 \\
\hline 6 & 97,84 \\
\hline 7 & 96,77 \\
\hline 8 & 96,43 \\
\hline 9 & 96,4 \\
\hline Jumlah & 882,17 \\
\hline Rata-Rata & 98,02 \\
\hline
\end{tabular}

Tabel 2. Hasil Pemeriksaan Glukosa Serum Hemolisis

\begin{tabular}{|c|c|}
\hline Sampel & $\begin{array}{l}\text { Kadar Glukosa Darah } \\
\text { Sewaktu (mg/dl) }\end{array}$ \\
\hline 1 & 222,65 \\
\hline 2 & 205,02 \\
\hline 3 & 205,02 \\
\hline 4 & 209,2 \\
\hline 5 & 206,72 \\
\hline 6 & 206,74 \\
\hline 7 & 207,1 \\
\hline 8 & 208,45 \\
\hline 9 & 208,43 \\
\hline Jumlah & 1879,33 \\
\hline Rata-rata & 208,81 \\
\hline
\end{tabular}

Tabel 3. Hasil Pemeriksaan Kadar Glukosa Serum Hemolisis + Anti-Rh

\begin{tabular}{|c|c|}
\hline Sampel & $\begin{array}{l}\text { Kadar Glukosa Darah } \\
\text { Sewaktu (mg/dl) }\end{array}$ \\
\hline 1 & 100,75 \\
\hline 2 & 96,89 \\
\hline 3 & 95,72 \\
\hline 4 & 96,89 \\
\hline 5 & 95,24 \\
\hline 6 & 96,5 \\
\hline 7 & 96,38 \\
\hline 8 & 95,79 \\
\hline
\end{tabular}


Jurnal Analis Medika Biosains (JAMBS)

Vol.7, No.2, September 2020, pp. 93 - 100

ISSN: 2656-2456 (Online)

ISSN: 2356-4075 (Print)

\begin{tabular}{|c|r|}
\hline 9 & 94,86 \\
\hline Jumlah & 869,02 \\
\hline Rata-Rata & 96,56 \\
\hline
\end{tabular}

Dengan kadar glukosa pada reagen anti - Rh yang telah diperiksa adalah 0,008 mg/dl.

Diagram 1. Hasil Pemeriksaan Kadar Glukosa Serum Normal, Serum Hemolisis, dan Serum Hemolisis + Anti-Rh

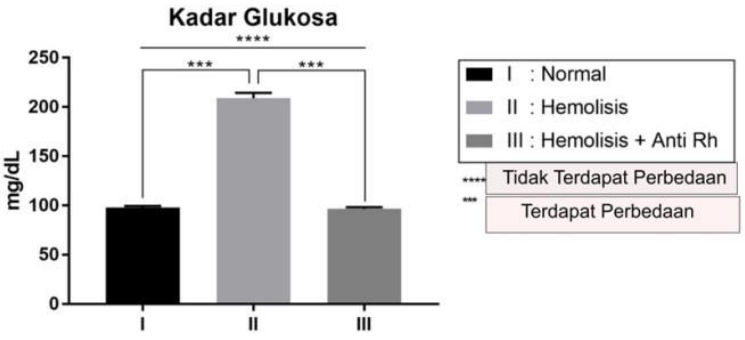

Diagram diatas menunjukkan hasil rata - rata kadar glukosa pada serum normal didapatkan rata - rata sebesar 98,02 mg/dl, pada serum hemolisis didapatkan rata - rata sebesar 208,81 mg/dl, pada serum hemolisis yang ditambahkan reagen anti - Rh didapatkan rata - rata sebesar 96,56 mg/dl. Terlihat adanya perbedaan antara serum hemolisis dengan serum normal dan serum yang telah ditambahkan reagen anti - Rh. Pada serum normal dan serum hemolisis yang ditambahkan reagen anti - Rh tidak terdapat perbedaan.

Kemudian dilakukan uji Friedman Test untuk mengetahui apakah hasil pemeriksaan glukosa pada pada serum normal, serum hemolisis, dan serum hemolisis yang ditambahkan reagen anti - Rh memiliki perbedaan yang signifikan.

\section{Table. 4. Uji Friedman 1}

\begin{tabular}{|c|c|c|c|}
\hline $\mathbf{N}$ & Chi-Square & df & Asymp. Sig. \\
\hline 2 & 16,222 & 2 &, 000 \\
\hline
\end{tabular}

Berdasarkan tabel di atas yang membandingkan nilai dari semua perlakuan pada sampel dan didapatkan nilai sig 0,000 . Nilai tersebut lebih kecil dari alpha $(0,05)$ yang berarti data memiliki perbedaan yang signifikan.

Tabel 5. Hasil Uji Friedman 2

\begin{tabular}{|c|c|c|c|}
\hline & $\begin{array}{l}\text { Hemolisis - } \\
\text { Normal }\end{array}$ & $\begin{array}{l}\text { Hemolisis+AntiRh - } \\
\text { Normal }\end{array}$ & $\begin{array}{l}\text { Hemolisis+AntiRh - } \\
\text { Hemolisis }\end{array}$ \\
\hline Z & $-2,666(a)$ & $-1,955(b)$ & $-2,666(b)$ \\
\hline $\begin{array}{l}\text { Asymp. Sig. (2- } \\
\text { tailed) }\end{array}$ & ,008 & 051 &, 008 \\
\hline
\end{tabular}


Tabel diatas menggambarkan hasil uji Friedman yang membandingkan antara serum hemolisis dengan serum normal, serum hemolisis yang ditambah anti - Rh dengan serum normal, dan serum hemolisis dengan serum hemolisis yang ditambahkan anti - Rh. Dapat diartikan bahwa antara serum normal dan serum hemolisis memiliki perbedaan yang sangat signifikan, sehingga serum hemolisis sangat berpengaruh pada pemeriksaan glukosa. Antara serum normal dan serum hemolisis yang telah ditambahkan anti - Rh tidak memiliki perbedaan yang signifikan, sehingga serum hemolisis yang ditambahkan reagen anti - Rh dapat digunakan kembali untuk pemeriksaan glukosa darah.

Pemeriksaan gukosa pada penelitian ini dilakukan dengan menggunakan metode GOD - PAP. Metode ini merupakan suatu metode pemeriksaan glukosa darah secara enzimatik, dimana kadar glukosa sebagai substrat akan dihidrolisis dengan bantuan glukosa oksidase menghasilkan asam glukonik dan $\mathrm{H} 2 \mathrm{O} 2$. Kemudian $\mathrm{H} 2 \mathrm{O} 2$ yang dilepaskan akan bereaksi dengan 4 - aminophenazone dan phenol dengan bantuan peroksidase menghasilkan zat warna qunoneimine yang berbanding lurus dengan substrat yang terdapat pada sampel. Penelitian ini bertujuan untuk mengetahui adanya pengaruh reagen anti - Rh untuk mengolah serum hemolisis pada pemeriksaan glukosa darah.

Sampel serum yang digunakan untuk pemeriksaan glukosa tidak diperbolehkan hemolisis. Sampel hemolisis dapat mempengaruhi hasil pemeriksaan. Eritrosit yag pecah mengeluarkan kompone - komponennya termasuk kandungan glukosa di dalamnya, sehinggan dapat meningkatkan hasil pemeriksaan kadar glukosa darah. Sedangkan hemoglobin yang keluar kedalam serum dapat menyebabkan gangguan kromogen pada kolorimetrik sehingga gangguan kromogen ini menyebabkan peningkatan intensitas warna dimana terjadi peningkatan absorbansi yang dibaca oleh fotometer. Pada penelitian ini mengolah sampel hemolisis agar tidak lisis kembali dan dapat digunakan untuk pemeriksaan glukosa darah, dengan menambahkan reangen anti - Rh ke dalam serum hemolisis. Penambahan reagen anti - Rh bertujuan untuk mengikat hemoglobin yang termasuk komponen protein di dalam eritrosit saat eritrosit pecah maka hemoglobin berada di dalam serum hemolisis, agar sampel hemolisis tersebut dapat digunakan kembali untuk pemeriksaan glukosa darah.

Berdasarkan penelitian yang telah dilakukan, berupa kadar glukosa darah serum normal didapatkan hasil rata-rata 98,02 mg/dl. Pada serum hemolisis didapatkan hasil 208, $81 \mathrm{mg} / \mathrm{dl}$. Pada serum hemolisis yang telah ditambahkan reagen anti - Rh didapatkan hasil 96, 56 mg/dl. Selanjutnya dilakukan uji Friedman, uji Friedman adalah salah satu uji non - parametrik dalam kelompok prosedur untuk sampel independen. Prosedur ini digunakan ketika kita ingin membandingkan dua variabel yang diukur dari sampel yang tidak sama (bebas). Hasil yang didapatkan dari uji Friedman menunjukkan bahwa pada pemeriksaan glukosa serum memiliki nilai signifikan 0,008 pada serum hemolisis memiliki hasil yang berbeda signifikan dengan sampel serum normal. Pada pemeriksaan glukosa pada serum hemolisis yang ditambahkan reagen anti-Rh memiliki nilai signifikan 0,051 yang dibandingkan dengan serum normal, yang berarti tidak berbeda signifikan terhadap serum normal. Pada serum hemolisis yang ditambahkan ragen anti-Rh memiliki nilai signifikan 0,008 yang dibandingkan dengan serum hemolisis, yang berarti bahwa memiliki perbedaan signifikan. 
Hasil pemeriksaan kadar glukosa serum, serum hemolisis dan serum hemolisis yang ditambahkan reagen anti - Rh ditemukan perbebaan. Secara klinis, perbedaan ini dapat dianggap bermakna karena adanya teori yang mendukung yaitu kadar glukosa serum hemolisis dapat menyebabkan kenaikan palsu yang disebabkan oleh keluarnya glukosa yang terdapat di dalam eritrosit, sehingga kadar glukosa serum hemolisis secara teori lebih tinggi dibandingkan serum normal. Selain itu pada serum hemolisis yang ditambahkan reagen anti - Rh tidak memiliki perbedaan terhadap serum normal, karena secara teori reagen anti - Rh akan mengikat protein - protein lain selain antigen spesifiknya jika dibiarkan terlalu lama. Anti-Rh dapat menurunkan kadar glukosa darah kembali seperti serum normal.

\section{Kesimpulan}

Pada penelitian ini penggunaan reagen anti - Rh dapat mengendapkan dan memisahkan eritrosit dengan serum dalam serum hemolisis. Ditandai dengan menurunnya kadar Hb pada serum hemolisis yang telah ditambahkan reagen Anti - Rh menjadi 0,04 g/dl dari kadar hb serum hemolisisnya 0,42 g/dl, dengan kadar glukosa rata - rata 208,81 mg/dl menjadi $96,56 \mathrm{mg} / \mathrm{dl}$. Tidak terdapat perbedaan bermakna antara kelompok normal dengan hemolisis + Anti - Rh. Kadar glukosa darah pada serum normal memiliki rata - rata 98,02 mg/dl. Kadar glukosa darah pada serum hemolisis memiliki rata - rata 208, $81 \mathrm{mg} / \mathrm{dl}$ dan pada serum hemolisis dengan penambahan reagen anti - Rh memiliki rata - rata 96, $56 \mathrm{mg} / \mathrm{dl}$.

\section{Daftar Pustaka}

Bell, D. S. (2001). Importance of postprandial glucose control. Southern Medical Journal,94(8), 804-804.

Bott, R. (2014). Guyton and Hall Textbook of Medical Physiology 13ed. Igarss 2014. Saunders Elsevier. 2 [online], Tersedia https://doi.org/10.1007/s13398-014- 0173-7.2 (19 Maret 2019).

Cambell, N, A. 2008. BIOLOGI edisi kedelapan jilid 1. Erlangga. Jakarta.

Guniar, R. (2012). Interferensi Suspensi Eritrosit Lisis Dalam Serum (Presipah Dan Presinorm) Dengan Metode GOD - PAP. Karya Tulis Ilmiah ,Sekolah Tinggi Analis Bakti Asih Bandung.

Hendromartono, Consensus on the Management of Diabetes Mellitus (Perkeni 1998). In Surabaya Diabetes Update. VI. Eds Tjokroprawiro A, Hendromartono, dkk. Surabaya 1999: 1 - 14.

Kitchen, S., Olson, J. D., \& Preston, F. E. (2009). Quality in Laboratory Hemostasis and Thrombosis.

MC, Pherson R dan Pincus M. (2011). Herry's Clinical Diagnosis and management by Laboratory Method.22 ed. Elsevier, 3:24-36 201.

McPherson. R. A \& Pincus, MR. (2011), Henry’s Clinical Diagnosis and Management Laboratory Method, 22nd Edition Elaevier Saunders, Philadelphia, pp 34-515.

Mikesh, L. M., \& Bruns, D. E. (2008). Stabilization of glucose in blood specimens: mechanism of delay in fluoride inhibition of glycolysis. Clinical Chemistry, 54(5), 930-932.

Ramadhantie, Miranda Ayu. (2013). Pengaruh Hemolisis Pada Pemeriksaan Ureum Menggunakan Metode Berthelot. Karya Tulis Ilmiah, Politeknik Kesehatan Bandung. 
Jurnal Analis Medika Biosains (JAMBS)

Vol.7, No.2, September 2020, pp. 93 - 100

ISSN: 2656-2456 (Online)

ISSN: 2356-4075 (Print)

Riyani, A. (2014). Penuntun Pratikum Kimia Klinik 1 Untuk Mahasiswa Analis Kesehatan. Edisi IV. Bandung.

Widjaja, Andi.et al. 2005. Panduan Mutu Laboratorium Klinik. Jakarta: PDS PATKLIN. 